\title{
VYBRANÁ SPECIFIKA PRACOVNĚPRÁVNÍCH SPORŮ V ZAHRANIČNÍM SROVNÁNÍ
}

\author{
PATRIK STONJEK
}

\begin{abstract}
Selected specifics of labour law disputes in international comparation
In the submitted text, the author attempts to present some chosen specifics of labour law disputes with a view to differences in court procedure. The author focuses more detailed on composition of labour courts/senates by lay judges and on their role by decision-making of labour law disputes and on financial demands of litigation of labour law disputes before courts.
\end{abstract}

Keywords: labour law disputes; court procedure; lay judges; court costs

Klíčová slova: pracovněprávní spory; soudní proces; př́isedící; náklady soudního řízení

DOI: $10.14712 / 23366478.2019 .10$

\section{ÚVOD}

Pracovněprávní vztahy jsou na rozdíl od jiných občanskoprávních nebo obchodněprávních vztahů jedinečné. Tato jedinečnost spočívá v délce a intenzitě jejich trvání, kterou lze srovnávat pouze s rodinnými vztahy. Z toho důvodu by měl zákonodárce zajistit, aby v pracovněprávních vztazích vznikalo co nejméně konfliktů. Vyvstalé spory by pak měly být řešeny rychle a efektivně a měly by vést $\mathrm{k}$ usmírení jejich stran, a to nejlépe za účelem jejich další spolupráce. ${ }^{1}$

Specifičnost pracovněprávních vztahů odůvodňuje zvláštní právní úpravu soudního procesu, jehož předmětem tyto vztahy jsou. V kontinentální i anglosaské právní kultuře je takovýchto odlišností mnoho. Jedná se např. o existenci zvláštní soudní soustavy nebo specializovaných senátů obecných soudů, účast laiků na rozhodování soudů, zvýhodnění při placení soudních poplatků, kratší lhůty pro rozhodování v pracovněprávních věcech, nevázanost soudu uplatněným návrhem, uplatnění zásady vyšetřovací, omezení koncentrace řízení, otočení důkazního břemene, zvláštní pravidla u náhrady nákladů soudního řízení v př́ípadě podání neúspěšné/ho žaloby/návrhu, speciální úpra-

* Autor je advokátním koncipientem a interním doktorandem na katedře pracovního práva a práva sociálního zabezpečení na Právnické fakultě Univerzity Karlovy.

1 Srov. MORGENWECK, J. Die Arbeitsgerichtsbarkeit in England. Frankfurt am Mein: Petr Lang, 2013, 156 s. ISBN 978-3-631-62756-3, s. 7. 
vu vykonatelnosti rozhodnutí soudů v pracovněprávních věcech nebo odlišné důvody umožňující využití rádných i mimořádných opravných prostředků.

Český právní řád mnoho specifik soudního procesu, jehož předmětem jsou pracovněprávní věci, neobsahuje. S výjimkou senátů, které rozhodují pracovněprávní spory v prvním stupni, lze zmínit ,zastoupení cizinců právnickou nebo fyzickou osobou sledujicich ochranu jejich práv; není nutné skládat jistotu spolu s návrhem na vydání predběžného opatření; je předpokládán zvláštní režim pro hodnoceni di̊kazů ohledně tvrzení, že došlo k př́mé nebo nepřimé diskriminaci; pro část pracovní odměny je upravena predběžná vykonatelnost"; u peněžitých plnění se neuplatní omezení př́ípustnosti dovolání. ${ }^{2}$ Vlastní průběh soudního rrízení v pracovněprávních věcech se tak v podstatě téměř vůbec neliší od klasického soudního řízení. V minulosti tomu tak však nebylo. ${ }^{3}$

V následujícím textu se budu věnovat vybraným odlišnostem pracovněprávních sporů vedených před soudy. Zejména budou představeny ty, které český právní řád nezná (resp. zná, ale v jiné podobě). Krátce budou okomentovány i odlišnosti spíše společenského charakteru, a to ve Spolkové republice Německo a v Rakouské republice, které utvářejí tamní pracovněprávní soudní proces (dále též jako ,„pracovněprávní proces").

\section{LAICKÝ PRVEK V PRACOVNĚPRÁVNÍM SOUDNÍM PROCESU}

Nejviditelnějším projevem jedinečnosti pracovněprávního procesu v České republice je existence soudního senátu před soudem prvního stupně, který je složen z jednoho soudce a dvou př́sedících - soudců z lidu. Jedná se o realizaci možnosti, která je uvedená v čl. 94 Ústavy, aby se na rozhodování soudů podíleli vedle soudců i další občané. Soudcům z lidu se věnoval již Václav Hora ${ }^{4}$ v publikaci Československé právo procesní, uvádějíc: „Ovšem ale sluši s důrazem upozorniti na jednu věc. Tento názor o spolupůsobení soudců z lidu při výkonu soudnictví předpokládá jen takové soudce z lidu, kteři by svými znalostmi životními zaručovali splnéní toho, co by bylo lze od nich pro zlepšeni soudnictvi podle shora naznačeného očekávati, a kteři by při tom byli proniknuti poctivou snahou, dopomáhati $k$ vitězství jen pravdě, spravedlnosti, naprostou nestranností a úzkostlivou svědomitostí, kteř́ by nespatrovali ve svém úradě ani nepohodlné bremeno ani vhodný plášt' pro uplatňování svého stranictvi (at'v jakémkoli směru), nýbrž jen a jen nejvyšší, ale i nejodpovědnějši poctu občanskou. K tomu bude zapotrebi ještě dlouholeté výchovy občanské. “ Tomuto historickému ${ }^{5}$ pojetí prrísedícího odpovídá i současný $§ 60$ odst. 1 zákona č. 6/2002 Sb., o soudech a soudcích, (dále též

2 HROMADA, M. Pracovněprávní spory. 1. vyd. Praha: C. H. Beck, 2015, 214 s. ISBN 978-80-7400-581-7. S. VII.

3 K historii pracovněprávního soudnictví viz např. PIRCHT, J. - ŠTEFKO, M. - MORÁVEK, J. Analýzy alternativnich zpi̊sobů řě̌eni sporů v pracovněprávních vztazich. Praha: Wolters Kluwer, 2016, 407 s. ISBN 978-80-7552-138-7, s. 118 a následující.

4 HORA, V. Československé právo procesní. I.-III. díl. Praha: Wolters Kluwer ČR, 2010, ISBN 978-807357-540-3. Díl. I., s. 65.

5 Citované dílo Václava Hory pochází z roku 1934. 
jako „ZoSaS“), který jako podmínky vzniku výkonu funkce př́isedícího stanovuje státní občanství České republiky, svéprávnost, bezúhonnost, věk nejméně 30 let a zkušenosti a morální vlastnosti, zaručující rádné zastávání funkce. Odbornost není (bohužel) v současné době po príísedících vyžadována. ${ }^{6}$

Přísedící jsou voleni zastupitelstvy obcí (v Praze zastupitelstvy městských částí) v obvodu prŕslušného okresního (v Praze obvodního) soudu (§ 64 odst. 2 zákona o soudech a soudcích). Kandidáti do funkce přísedících, kterými mohou být pouze občané mající trvalý pobyt nebo pracující v obvodu zastupitelstva, jímž jsou do funkce voleni, jsou navrhováni členy príslušného zastupitelstva s tím, že zastupitelstvo si k navrženým kandidátům vyžádá vyjádření předsedy př́slušného soudu. ${ }^{7}$ Jednotliví kandidáti do funkce př́isedících jsou tak z hlediska jejich zkušeností a morálních vlastností hodnoceni $\mathrm{v}$ podstatě pouze členy př́slušného zastupitelstva a předsedou př́slušného soudu. Ostatní osoby se k nim mohou vyjádřit toliko za situace, že se dostaví na schůzi zastupitelstva, kde se o jednotlivých kandidátech bude hovořit. ${ }^{8}$

Zásadním nedostatkem u př́sedících je již zmíněný chybějící požadavek na jejich odborné znalosti z pracovněprávní praxe, které by z nich činily cenné pomocníky při rozhodování pracovněprávních sporů, jejichž znalosti nejsou (pouze) teoretické, ale především praktické. ${ }^{9}$ Jmenované kritérium obsahuje německý zákon o pracovních soudech z roku $1953^{10}$ (dále též jako „ArbGG“) toliko u přísedících, kteří působí u Spolkového pracovního soudu ${ }^{11}$, nicméně z vlastní zkušenosti ${ }^{12}$ mohu říct, že i př́ísedící (tzv. čestní soudci - ehrenamtliche Richter ${ }^{13}$ ), kteří jsou činní na nižších soudních instancích, tedy na pracovních a zemských pracovních soudech, velice solidními znalostmi z pracovněprávní praxe skutečně disponují. K čestným soudcům Bader ${ }^{14}$ uvádí: „Čestní soudci mají vnést do výkonu soudni pravomoci jejich zvláštni odbornost. ${ }^{15}$ Proto je chybné nazývat čestné soudce v sociálním a pracovním soudnictví jako, laické soudce; nejedná se totiž pouze o ctihodné občany, u kterých se pořadí výběru určuje losem (jako o porotců/soudců z lidu), ale o ženy a muže, kteři byli navrženi právě kvi̊li jejich odbor-

6 Srov. WINTEROVÁ, A. - MACKOVÁ, A. a kol. Civilní právo procesní. Prvni část- Řizení nalézací. Praha: Linde, 2014, 624 s. ISBN 978-80-7201-940-3, s. 124.

7 Viz $§ 64$ odst. 3 a 4 ZoSaS.

8 K délce funkčního období, skládání slibu atp. viz $§ 60$ a násl. zákona o soudech a soudcích.

9 Srov. PICHRT, J. - ŠTEFKO, M. - MORÁVEK, J. Analýzy alternativnich způsobů re rěeni sporů v pracovněprávnich vztazich. S. 194.

10 V originále se jedná o Arbeitsgerichtsgesetz, který je dostupný na: <www.gesetze-im-internet.de> [cit. 14. 11. 2018].

11 Viz $§ 43$ odst. 2 věta druhá ArbGG. S ohledem na to, že se jedná o jednu z nutných podmínek pro výkon funkce př́ísedícího u Spolkového pracovního soudu, mohlo by být $\mathrm{v}$ př́ípadě jejího nedostatku zahájeno řízení o zbavení funkce př́isedícího, který by zvláštními znalostmi a zkušenosti nedisponoval (srov. LIEBSCHER, in SCHWAB, N., WETH, S., a kol. Kommentar zum Arbeitsgerichtsgesetz. 2 Auflage. Köln: Verlag Dr. Otto Schmidt KG, 2007, 2682 s. S. 755, m. č. 9.).

12 Jedná se o zkušenosti nabyté na stáži absolvované na Pracovním soudu v Münsteru a Zemském pracovním soudu v Hammu.

13 Ačkoliv není zcela správné nazývat německé čestné pracovněprávní soudce českým pojmem přisedící, budu tak i nadále činit, a to $\mathrm{z}$ toho důvodu, aby nedocházelo $\mathrm{k}$ matení čtenářů.

14 BADER, in BADER, P. - HOHMANN, R. - KLEIN, H. Die ehrenamtlichen Richterinnen und Richter in der Arbeits- und Sozialgerichtsbarketi. 13. neu bearbeitete und erweiterte Auflage. Heidelberg: C. F. Müller, 2012, 315 s. ISBN 978-3-8114-7014-9. S. 1.

15 Zde cituje shora jmenovaný autor Liebschera (LIEBSCHER, in SCHWAB, WETH, § 6 Rn. 48). 
nosti ${ }^{16}$. Na jiném místě Bader zdůrazňuje, že pracovněprávní proces není od začátku a dnes ještě víc myslitelný bez odborného porozuměni prísedícich. Toto odborné porozumění se ovšem nevztahuje na to, že přisedící jsou znalejši práva než soudci. Odborné porozuměni, které bylo jmenováno na tomto mistě, se právě prednostně neodvozuje od odborných znalostí práva, ale vztahuje se na reálné zkušenosti a znalosti dění v provozu, závodu, hospodáŕství a pracovním životè.."17

Odbornost př́isedících je implicitním požadavkem výkonu jejich funkce na všech soudních instancích v Rakouské republice, viz § 10 odst. 2 zákona o pracovních a sociálních soudech z roku $1985^{18}$ (dále též jako „ASGG“), který hovoří o odborných laických soudcích ${ }^{19}$ (fachkundige Laienrichter). Jejich významnou úlohu vyzdvihuje např. Neumayr ${ }^{20}$, která poznamenává, že „důležitý úkol odborných laických soudců spočivá $v$ poskytnutí jejich zvláštnich odborných znalost ${ }^{21}$, ale také ve zvýšení akceptace rozhodnuti pracovnich a sociálnich soudư “22.

Německy mluvící odborná veřejnost se tak jednoznačně shoduje na přínosu přísedících v pracovněprávních sporech, a to zejména s ohledem na jejich odborné znalosti. Tento názor je ale sdílen i za hranicemi Rakouské republiky nebo Spolkové republiky Německo, a to ve Francii a Spojeném království Velké Británie a Severního Irska. Potvrzují jej rozhovory, které byly vedeny výzkumníky s tamními př́sedícími a soudci. ${ }^{23}$

U českých soudů mám velmi často pocit, že přísedící v pracovněprávních věcech nejsou dostatečně motivovaní, diplomaticky řečeno. ${ }^{24}$ Při jednáních působí mnohdy nepř́tomně, čímž vyvstávají otázky, jestli jsou př́nosem pro pracovněprávní soudnictví. Navíc se mnohdy jedná o osoby důchodového věku, o jejichž znalostech pracovního prostředí tržní ekonomiky je možné přinejmenším pochybovat. ${ }^{25}$

16 Na tomto místě pak shora uvedený autor odkazuje na judikaturu německého ústavního soudu, a to např na jeho rozhodnutí BVerfG ze dne 22. 1. 1959 - 1 BvR 154/55 - BVerfGE 9 nebo ze dne 4. 6. 1969 2 BvR 412/66, a na další rozhodnutí německých nejvyšších soudů.

17 BADER, in BADER, P. - HOHMANN, R. - KLEIN, H. Die ehrenamtlichen Richterinnen und Richter in der Arbeits- und Sozialgerichtsbarketi. S. 3.

18 V originále se jedná o Arbeits- und Sozialgerichtsgesetz, který je dostupný na www.ris.bka.gv.at [cit. 17. 11. 2018].

19 I v př́ípadě rakouských čestných soudců budu dále v textu používat český pojem př́isedící.

20 NEUMAYR, in NEUMAYR, M. - REISSNER, G., P. Zeller Kommentar zum Arbeitsrecht. 3. Auflage. Wien: MANZ Verlag Wien, 2018, 3860 s. ISBN 978-3-214-03821-2. § 10, m. č. 3.

21 Zde cituje výše uvedený autor Kudernu (KUDERNA, ASGG 109).

22 Na tomto místě pak shora jmenovaný autor odkazuje na Kurase (KURAS, ZAS 2012, 321), Haidera (HAIDER, Wohltat 182) nebo Greifenedera (GREIFENEDER, ZAS 2012, 321).

23 BUGERSS, P., et al. The roles, resources and competencies of employee lay judges. A cross-national study of Germany, France and Geat Britain. Düsseldorf: Hans-Böckler-Stiftung, 2017, 92 s. ISSN 2509-2359. S. 6. Podobné rozhovory jsem také vedl, a to s německými a rakouskými soudci a príísedícími, a mohu vše, co bylo uvedeno výše, potvrdit.

24 Srov. PICHRT, J. - ŠTEFKO, M. - MORÁVEK, J. Analýzy alternativnich způsobi̊ řešeni sporů v pracovněprávnich vztazich. S. 194.

25 V prosinci roku 2017 působilo na Městském soudu v Brně, na Obvodním soudu pro Prahu 9 a na Okresním soudu v Karviné, Liberci, Náchodě, Nymburce, Pelhřimově a Tachově celkem 115 př́sedících v pracovněprávních věcech, jejichž průměrný věk byl 63 let. $Z$ toho byli pouze 4 př́isedící ve věku $31-40$ let a 37 př́sedících ve věku 71 a více let. Nejvyšší průměrný věk přísedících vykazoval Okresní soud v Náchodě, a to 71 let. Okresního soud v Pelhřimově byl naopak obsazen nejmladšími př́sedícími, kterým bylo v průměru 58 let. Tato data mi byla v citovaném období poskytnuta jmenovanými soudy. 
Věk ale zcela jistě není překážkou toho, aby mohl přísedící dobře vykonávat svou funkci. Setkal jsem se s př́sedícím, kterému bylo více než 90 let, ale který svými faktickými, ale i právními znalostmi pracovněprávního prostředí a pracovního práva převyšoval mnoho (možná i většinu) osob živících se právem, které znám; nutno dodat, že jeho praxe (jakožto laika) u soudů čítala více než 35 let. Jednalo se však o jediného př́sedícího, se kterým jsem se dosud v České republice potkal, který by pokládal dotazy i během samotného soudního jednání. I v tomto jsou němečtí nebo rakouští príísedící mnohem aktivnější, což minimálně vyvolává během soudního jednání dojem, že (1) sledují př́ípad a (2) že mu rozumí, příp. se jej snaží pochopit. Jednou jsem se v Německé spolkové republice setkal s př́ísedícím, který byl natolik horlivý, že během soudního jednání přerušil soudkyni slovy „počkejte, počkejte“. ${ }^{26}$ To je samožrejmě věc, která by se stávat neměla, protože snižuje autoritu soudce před účastníky soudního jednání a může i narušit jeho průběh. I navzdory tomu ale zastávám názor, že dotazy př́sedících ke skutkovým otázkám případů jsou na místě, protože se jedná o oblast, kde praktická znalost prrísedících pracovního prostředí může soudci velmi pomoci.

Chybějící odborné znalosti a prínos přísedících (nejen v pracovněprávních sporech) je českou veřejností mnohdy kritizován a vede $\mathrm{k}$ diskuzím o zrušení tohoto institutu. Záruku jistého stupně odbornosti př́sedících ve všech jmenovaných státech poskytují zástupci zaměstnanců a zaměstnavatelů, kteří se na výběru a nominaci príisedících podílejí. Podle vyjádření zaměstnaneckých organizací působících v České republice ale tento způsob výběru přísedících nepřipadá ani de lege ferenda $\mathrm{v}$ úvahu, a to $\mathrm{z}$ důvodů kapacitních. Je však nutné si uvědomit, že zástupci zaměstnanců a zaměstnavatelů by neměli na místa prísedících navrhovat pouze své členy, ale i jiné osoby, které by splňovaly podmínky, o kterých bylo výše pojednáváno. Je tedy otázkou, jestli se nejedná pouze o strach nebo obavy z prrevzetí zodpovědnosti za výběr a nominaci přísedících ze strany těchto subjektů.

Otázku odměňování př́sedících nechávám zcela stranou tohoto př́spěvku. Dovolím si toliko poukázat na vyhlášku ministerstva spravedlnosti České republiky č. 44/1992 Sb., o náhradách za vykonávání funkce př́sedícího, která platí v nezměněné podobě od 1. 1. 1996. Od roku 1996, kdy průměrná hrubá mzda činila 9.825 Kč/měsíčně, se odměny prísedících podle jmenované vyhlášky nezměnily, a to navzdory tomu, že průměrná hrubá mzda za 2 . čtvrtletí roku 2018 činila již $31.851 \mathrm{Kč} /$ měsíčně. ${ }^{27}$ Funkce prrísedícího je čestnou, ale zároveň veřejnou funkcí. Výše odměny by však neměla být jen symbolická, ale měla by i do jisté míry odrážet náročnost a důležitost výkonu funk-

\footnotetext{
26 Na jiném soudním jednání u odvolacího soudu jeden německý přísedící při rodícím se narovnání upozorňoval účastníky soudního řízení na to, že zkrácení pracovní doby zaměstnankyně, o kterém se v ten moment vedla diskuze, bude vyšší, než kterého se domáhala. Činil tak podle mého názoru s dobrým úmyslem, aby zaměstnavatel nebyl posléze překvapen, že zaměstnankyně je méně v práci, než původně čekal, a aby nebyla překvapena i zaměstnankyně, že její mzda bude nižší, než původně čekala. Toto upozornění však mohlo vyústit v neuzavření dohody. Díky zkušenosti soudce však všichni jmenovaný výrok přísedícího přešli bez větší pozornosti a dohoda mezi zaměstnavatelem a zaměstnankyní nakonec byla ke spokojenosti všech uzavřena.

27 Tato data jsou dostupná online na: <www.czso.cz> [cit. 17. 11. 2018].
} 
ce přísedícího. Blíže k této problematice viz Pichrt, Štefko a Morávek ${ }^{28}$ nebo Burgess a kol. ${ }^{29}$

\section{PŘÍSTUP K SOUDŮM}

Otázka přístupu $\mathrm{k}$ soudům je často diskutovaným tématem u těch skupin obyvatelstva, které nejsou dostatečně materiálně zajištěné. Zahájení civilního soudního řízení spolu nese zpravidla 3 typy nákladů, které musí každý žalobce/navrhovatel zvážit před tím, než samotné soudní rízení zahájí. Jedná se o náklady (1) na vlastní zastoupení, (2) na soudní poplatek a (3) na náhradu nákladů ř́zení protistraně, pokud žalobce/ navrhovatel nebude $\mathrm{v}$ ř́zení úspěšný. ${ }^{30}$

Česká právní úprava nezná $\mathrm{v}$ tomto ohledu téměř žádná specifika. Zmínit tak lze toliko osvobození od soudního poplatku navrhovatele $\mathrm{v}$ ř́zení o náhradu škody z pracovního nebo služebního úrazu a nemoci z povolání [viz § 11 odst. 2 písm. e) zákona č. 549/1991 Sb., o soudních poplatcích] a neexistenci povinnosti navrhovatele složit jistotu k zajištění náhrady škody nebo jiné újmy u předběžných opatření v pracovních věcech [viz $\S 75$ b odst. 3 písm. b) zákona č. 99/1963 Sb., občanský soudní řád]. V převládající soudní agendě, která je $\mathrm{v}$ pracovním právu tvořena spory o neplatnost skončení pracovněprávních vztahů a spory týkající se odměňování a jiných finančních vztahů, se tyto dvě výjimky nepoužijí. ${ }^{31}$ Zahraniční právní úprava a celkově i tamní nastavení společnosti jsou v tomto ohledu mnohem př́iznivější, což tamním zaměstnancům umožňuje účinně chránit jejich práva. Samotné zakotvení hmotněprávních oprávnění zaměstnanců totiž není bez adekvátních procesních pravidel účinné.

V Rakouské republice mají nepřehlédnutelné postavení komory pracovníků (tzv. Arbeiterkammern). Tyto komory jsou legislativně upraveny v zákoně o komorách pracovníků z roku $1992^{32}$ (dále též jako „AKG“), který jim ve svém úvodním ustanovení $\S 1$ - stanovuje úlohu spočívající v zastupování a podpoře sociálních, hospodářských, zaměstnaneckých a kulturních zájmů zaměstnanců a zaměstnankyň. Rakouský pojem zaměstnance je pro účely jmenovaného zákona širší než česká definice zaměstnance. Proto bude na tomto místě odkázáno na $\S 10$ odst. 1 a 2 AKG a odbornou literaturu ${ }^{33}$, která se pojmu zaměstnance tak, jak je chápán v Rakouské republice, věnuje.

28 PICHRT, J. - ŠTEFKO, M. - MORÁVEK, J. Analýzy alternativnich způsobů řešení sporů v pracovněprávních vztazích. S. 195 a 196.

29 BUGERSS, P., et al. The roles, resources and competencies of employee lay judges. A cross-national study of Germany, France and Geat Britain. S. 32 a 33.

30 Uvažována zde bude typická situace, kdy si žalobce/navrhovatel zvolí zástupce z řad advokátů, bude nutné zaplatit soudní poplatek a žalovaný/odpůrce bude rovněž zastoupen zástupcem z řad advokátů.

31 Srov. přehled o pravomocných rozhodnutích soudů v občanskoprávních věcech podle druhu sporů za rok 2016, který je dostupný online na: <cslav.justice.cz> [cit. 17. 11. 2018]. Za citovaný rok se jednalo o 2.464 pravomocně rozhodnutých sporů z celkových 3.745 .

$32 \mathrm{~V}$ originále se jedná o Arbeiterkammersgesetz, který je dostupný online na: <www.ris.bka.gv.at> [cit. 17. 11. 2018].

33 MARHOLD, F. - FRIEDRICH, M. Österreichisches Arbeitsrecht. 3. Auflage. Wien: Verlag Österreich, 2016, 782 s. ISBN 978-3-70466494-5. S. 46 a následující. 
Členství v komorách pracovníků je povinné a jejich členové jsou povinni platit př́spěvky ${ }^{34}$ na chod těchto organizací (s výjimkami uvedenými v $§ 17$ odst. 2 AKG). Výši př́spěvků stanovuje valná hromada Spolkové komory pracovníků; ta je však při svém rozhodování omezena zákonnými limity (blíže viz § 61 odst. 2 AKG).

Pro účely tohoto článku je však nejdůležitější § 7 odst. 1 AKG, který komorám pracovníků ukládá radit jejich členům v pracovněprávních a sociálněprávních záležitostech a obzvláště jim poskytovat právní ochranu prostřednictvím zastupování u soudu v pracovněprávních a sociálněprávních záležitostech. Díky existenci komor pracovníků, které svým členům poskytují právní zastoupení před soudy, si tak jejich členové nemusí hledat zástupce z řad advokátů, kterým by museli platit honoráře přesahující 100 Euro/ hodinu. Povinné členství je však trnem v oku některým politickým subjektům, a proto se o něm nezř́íka kdy diskutuje. ${ }^{35}$

Ve Spolkové republice Německo lze zmínit rozšiřrenost pojištění právní ochrany, které do jisté míry supluje komory pracovníků známé z Rakouské republiky. V roce 2017 dosahoval počet uzavřených smluv, jejichž předmětem bylo pojištění právní ochrany, hodnoty 22 milionů. Pro úplnost lze poznamenat, že uzavření pojištění právní ochrany není ve Spolkové republice Německo uloženo žádným předpisem. Tamní společnost jej však považuje za důležitý způsob ochrany před potenciálními riziky, která mohou vyplynout $\mathrm{z}$ běžného života člověka.

Po obstarání zástupce, který př́slušný př́ípad z oblasti pracovního práva posoudí, je nutné podat žalobu/návrh na soud. S tím je spojená poplatková povinnost. Jedná se tedy v pořadí o druhý náklad, který je žalobce/navrhovatel nucen vynaložit, aby se mohl domoci svého nároku. Splatnost soudních poplatků v pracovněprávních věcech ve Spolkové republice Německo však nenastává již podáním žaloby/návrhu na soud, ale často až jejím vyř́zením (viz $§ 6$ odst. 3 ve spojení s $§ 9$ odst. 2 zákona o soudních poplatcích z roku $2004^{36}$ - dále též jako „GKG“). V Rakouské republice jsou pracovněprávní spory s hodnotou do 2.500 Euro dokonce osvobozeny od poplatků. ${ }^{37}$ Ve Spolkové republice Německo pak v př́ípadě uzavření smíru může dojít k odpadnutí poplatkové povinnosti. ${ }^{38}$ Jmenované instituty tak podstatným způsobem usnadňují zahájení soudního řízení v pracovněprávních věcech.

V neposlední řadě musí každý žalobce/navrhovatel zvážit, co může $\mathrm{v}$ př́ípadě neúspěchu jeho žaloby/návrhu ztratit. S výjimkou toho, že se před soudem nedomůže toho, o co usiloval, musí v civilním procesu očekávat, že ponese náklady, které vynaložil žalovaný/odpůrce, tedy jeho protivník. V pracovních věcech toto v Rakouské republice ani ve Spolkové republice Německo neplatí.

34 Průměrná měsíční výše př́spěvku činí 6,91 Euro, maximální výše příspěvku je omezena částkou ve výši 14,41 Euro, viz <www.arbeiterkammer.at> [cit. 17. 11. 2018].

35 Viz např. zpráva s názvem Heftige Debatte über AK-Beiträge und Kammer-Pflichtmitgliedschaft, která pochází z dubna roku 2015 a je dostupná online na: <www.parlament.gv.at $>$ [cit. 17. 11.2018].

$36 \mathrm{~V}$ originále se jedná o Gerichtskostengesetz, který je dostupný online na: <www.gesetze-im-internet.de> [cit. 17. 11.2018].

37 Viz poznámka č. 8 zákona o soudních poplatcích z roku 1997; v originále se jedná o Gerichtsgebührengesetz (dále též jako „GGG“), který je dostupný online na: <www.ris.bka.gv.at> [cit. 17. 11. 2018].

38 Viz část 8 GKG. 
Ve Spolkové republice Německo je právní úprava $\mathrm{v}$ tomto ohledu přehlednější. $\mathrm{V} \S 12 \mathrm{a}$ odst. 1 větě první ArbGG je stanoveno, že v rozsudkových řízeních ${ }^{39}$ prvního stupně nemá vítězná strana nárok na náhradu nákladů spočívajících v přibrání procesního zmocněnce nebo podpůrce/pomocníka. Rakouská právní úprava je v tomto ohledu velkorysejší, když nárok na náhradu nákladů připouští až v řízení u Nejvyššího soudního dvora (der Oberste Gerichtshof), který je nejvyšším soudem v rámci tamní soustavy obecných soudi̊. ${ }^{40}$

\section{ZÁVĚR}

Pracovněprávní soudnictví může vykazovat mnohá specifika. Česká právní úprava je ve srovnání s vyspělými státy západní Evropy téměř pravým opakem, protože $\mathrm{s}$ výjimkou př́sedících, kteř́ byli diskutováni v první polovině tohoto př́spěvku, nezná v podstatě žádný jiný právní institut, který by podstatnějším způsobem ovlivňoval pracovněprávní proces.

Za nestandardní lze označit, že čeští přísedící v pracovněprávních věcech nejsou vybíráni ani nominováni zástupci zaměstnanců a zaměstnavatelů, jak je tomu běžně zvykem. Stejně tak není zvykem, aby při výběru kandidátů na př́ísedící nehrála významnější roli ani jejich odborná znalost pracovního prostředí.

Ve druhé části této stati bylo hovořeno o př́istupu $\mathrm{k}$ soudům $\mathrm{v}$ pracovněprávních věcech. $\mathrm{V}$ tomto ohledu je česká právní úprava zcela nepoznamenaná. Inspiraci by bylo možné hledat ve Spolkové republice Německo nebo v Rakouské republice, a to např. formou snížení soudních poplatků v pracovněprávních věcech nebo zrušením náhrady nákladů řízení alespoň před soudem prvního stupně. Současný stav v této oblasti pak podle mého názoru odrazuje zejména hưr̆e situované zaměstnance, kteří by se rádi domáhali svých nároků podáním žaloby/návrhu, protože náklady v prípadě neúspěchu by pro ně byly neúnosné.

V roce 2016 bylo ve Spolkové republice Německo podáno více než 360 tisíc žalob/ návrhů $\mathrm{v}$ pracovněprávních věcech a téměř totožný počet jich byl vyř́zen. ${ }^{41}$ Ve Spojeném Království Velké Británie a Severního Irska bylo podáno za období finančního roku 2016/2017 přes 88 tisíc žalob/návrhů. ${ }^{42}$ V roce 2016 pak bylo v České republice vyřízeno přes 3,7 tis. žalob/návrhů v pracovních věcech; je možné předpokládat, že počet vyř́zzených věcí za toto období mohl být obdobný ${ }^{43}$. Na základě těchto údajů si

39 Jedná se o řízení uvedená $\mathrm{v} \S 12$ ArbGG, pod který by se dala zjednodušeně řečeno zařadit všechna řízení vyplývající z individuálního pracovního práva.

40 Okruh př́padů, na které tato právní úprava dopadá a na které odkazuje § 58 odst. 1 věta první ASGG, je uveden v $\$ 50$ odst. 2 ASGG, který odkazuje na část II., V., VI., VII. a VIII. zákona o pracovních zřízeních z roku 1973; v originálně se jedná o Arbeitsverfassungsgesetz (dále též jako „ArbVG“), který je dostupný online na: <www.ris.bka.gv.at> [cit. 17. 11. 2018]; zmiňované části ArbVG obsahují např. úpravu skončení pracovního poměru.

41 Viz < www.bmas.de $>$ [cit. 25. 6. 2018].

$42 \mathrm{Viz}<$ www.gov.uk $>$ [cit. 17. 11. 2018].

43 Bohužel se mi nepodařilo dohledat přesná data k počtu zahájených soudních řízení v pracovněprávních věcech. Nedomnívám se však, že by se můj předpoklad o přibližně stejné výši nově zahájených věcí 
lze udělat přibližný názor na to, jaký je přístup $\mathrm{k}$ soudům v pracovněprávních věcech $v$ těchto třech jmenovaných státech. ${ }^{44}$

I s ohledem na uvedená data doufám, že do českého procesního práva budou v budoucnu zapracovány alespoň některé instituty, které znají za hranicemi a které by umožnily účinněji hájit práva zejména zaměstnanců, kteří jsou $v$ drtivé většině případů skutečně těmi slabšími v pracovněprávních vztazích, čímž si zvýšenou ochranu nejen v hmotném právu zaslouží. Jestli se tomu tak ale skutečně stane, je otázkou.

Ing. Mgr. Patrik Stonjek

Právnická fakulta Univerzity Karlovy

stonjek.patrik@seznam.cz

a o počtu vyřízených starších případů zásadně odchyloval od reality. Průměr vyřízených pracovních věcí za roky 2010-2017 činil přibližně 4,6 tis. žalob/návrhů.

44 Spojené království Velké Británie a Severního Irska jsem vybral z toho důvodu, že se jedná o nejméně sociálně orientovaný stát ze všech, které byly v tomto příspěvku zmíněny, a to navzdory tomu, že o něm nebylo podrobněji hovořeno. Jedná se tedy o údaj sloužící pro ilustraci čtenáře, jaký je nápad pracovněprávních věcí v různých částech Evropy, které se liší svým sociálním, kulturním i právním prostředím. 